$$
\text { 초치료 폐결핵환자에 관한 미래지향적 연구 }
$$

대한결핵협회 부산지부 부속의원

$$
\text { 이 찬 세·김 의 윤 }
$$

\title{
$=$ Abstract $=$
}

\section{A Prospective Study on Initial Treatment Cases of Pulmonary Tuberculosis}

\author{
Chan Sae Lee, M.D. and Yie Yoon Kim, M.D.
}

\author{
Pusan City Chapter Clinic of Korean Tuberculosis Association
}

The authors made a prospective study on 856 initial treatment cases of pulmonary tuberculosis registered at Pusan City Chapter Clinic of Korean Tuberculosis Association during last three and half years from 1983-8-1 to 1987-1-31. The results and conclusion are as follows;

1) The proportion of initial treatment cases to total pulmonary tuberculosis cases registered at this clinic was $29.8 \%$. This is more than double increase than the previous study made 17 years ago made by one of these authors.

2) The sex ratio of male to female was 1.7 to 1 . This means a definite increase of female ratio than the previous study. However it was similar with the one of the last National Tuberculosis Prevalence Survey and thought to be due to the increased actions of female patients for treatment rather than the increased disease among female population of the society.

3) There were $52.6 \%$ of minimal cases, $38.8 \%$ of moderately advanced, $8.6 \%$ of far advanced. The minimal cases ratio showed a definite increase than the previous study but the overall pictures were much similar with the last National Survey Results and it was also thought to be due to the increased treatment seeking activities of present cases.

4) The most prevalent age group was $21 \sim 30$ years old with a rate of $38.2 \%$ and the age group distribution showed a parabola type similar with the previous one. The trend of gradual increase of the morbidities toward to old age groups seen on the last National Survey was not yet seen on this study. This was taken as a result that the old age groups were still much hindered their treatment seeking actions by various reasons.

5) The overall sputum positive rate on diagnosis of these initial treatment cases was $34.0 \%$ while $9.6 \%$ had no examinations. These were explained that the lower positiveness was due to the larger proportion of the minimal cases and the lower no examination rate was due to the more cooperativeness of present cases than previous one.

6) The duration of the diseases after the onset or discovery until the registration among sputum positive cases showed that the more extensiveness of the pulmonary lesions had the longer durations as $76.7 \%$ of minimals in contrast to only $22.0 \%$ of far advanced cases were within 3 months duration.

7) About changeability classification of the pulmonary lesions on the admission, there were $28.6 \%$ of easily changeables, $27.0 \%$ of hardly changeables, and $44.4 \%$ of intermediate groups as a whole. The proportion of easily changeables were rather smaller than the previous study. It was explained by the 
fact of the larger numbers of asymptomatic sputum negative minimal cases among present study.

8) The classification of the modes of disease onset showed that $74.3 \%$ were gradual onset, $18.6 \%$ were found the diseases by the chest X-rays on various occasions, $5.1 \%$ were hemoptic, and $2.0 \%$ were with symptoms of acute pnenmonias. This and the former phenomenal differences between two studies were supposed to be due to the increased eagerness of getting the treatment by those patients among present study because of enlightend medical expenses under the national insurance policy. The proportions of onset modes of the discovering the diseases by the chest X-ray examinations remained same as ever and it was still one of important ways to bring the initial treatment cases of the pulmonary tuberculosis to the clinic.

9) About the duration of treatment at this clinic, $67.4 \%$ of the cases continued their treatment for more than 7 months, this was much improvement to compare the previous study due mainly to the benefits of the national insurance policy. Although $32.4 \%$ of the cases had only two to three visits, about half of them were discharged as inactive needed no treatment with negative sputum and unchangeable minimal lesions.

10) About the treatment results of the initial treatment cases, the sputum positives with $3 \sim 6$ months treatment showed that the negative conversion rates of $75.0 \%$ and the marked improvement of the pulmonary lesions in $25 \%$ of them. The effectiveness of these early treatment phase were similar with the previous study cases instead of marked increase of the chemotherapeutic combination regimes, namely RFP., PZ., CS., and EMB., in addition to SM., INH., PAS. The group of 7 10 months treated showed the sputum negative conversion rates of $97.2 \%$, the failure of negative conversion $2.8 \%$, the marked improvement of the pulmonary lesions $49.1 \%$, the worse progression of the lesions $2.8 \%$, and the final discharges with inactive states were $91.7 \%$. The results of more than 11 months treated group were the spuntum negative conversions $87.5 \%$, the failure of negative conversion $5.7 \%$, the marked improvement of the lesions $31.9 \%$, the worse progression of the the lesions $3.4 \%$, and the final discharges with inactive status were $87.5 \%$. As a whole the treatment results of these cases showed some improvements than the previous study cases.

11) Among the sputum negative cases on admission of this study, the sputum examinations thereafter became persistently positive in $1.7 \%$ of the $7 \sim 10$ month treated group and $1.8 \%$ of the more than 11 month treated group. The marked improvement of pulmonary lesions were $47.4 \%$ in the formers and $31.9 \%$ in the laters, the worse progression of the lesions were $1.7 \%$ and $1.8 \%$, the final attainments of inactive status were $97.1 \%$ and $96.4 \%$ respectively.

12) The moderately advanced group by the classification of the pulmonary lesions achieved the highest rates of the marked improvement of the pulmonary lesions but the largest rate of the attainment of inactive status were seen among the minimal case group. The failure of sputum negative conversion occurred more among the far advanced group. These results mean that even with present effective antituberculosis chematherpentic regimens, the early diagnosis and the early treatment were strongly required evermore.

13) On family history of the initial treatment patients, $11.1 \%$ of them revealed one or more of the pulmory tuberculosis history among their members. The majority of the family patients, $67.4 \%(7.5$ $\%)$ were presently on treatments, $23.2 \%(2.6 \%)$ were with past histories, $9.5 \%(1.1 \%)$ were died of pulmonary tuberculosis. About the family relationships, the most frequent ones were the fathers of the index cases with $28.4 \%(3.6 \%)$, the next were the siblings with $25.3 \%(2.8 \%)$, and the mothers with 21 . $1 \%(2.4 \%)$. The conjugal partners were rather small with $7.37 \%(0.8 \%)$. 
These results indicated that the ages of the index cases were rather young. There were 2 cases with 3 patients in each of their families and 1 case with 4 patients in a single family. In view of those facts the problems of tuberculosis in Korea should be considered as very much serious yet.

14) In conclusion the authors made following suggestions that the governmental health insurance system should be further extended rapidly along side with more active social welfare system enough to encourage the patients and medical service personals for more early diagnosis and for more regular early treatment of pulmonary tuberculosis by lowering the threshoulds of the medical services. That the treatment regimes also should be further broaded by lifting the limitations of so called fixed short terms chemotherapy policy at the public health service clinics.

That the public health education policy should also more actively be continued as ever.

\section{서}

론

현대적 결핵치료제 특히 리팜피신(이하 RFP로 약칭) 이 개발된 이래로 폐결핵의 치료와 근절은 시간과 의료 조직의 문제일 뿐이라고 ${ }^{1)}$ 했고 대체적으로 초진단 조치 료환자에 대한 치료효과는 거의 $100 \%$ 라고 선전되고 있 다. 그러나 이것은 규정된 조건에서 실험적으로 얻어진 결과를 기계적이고 산술적으로 확산 추론한 것에 불과하 다. 아직까지도 수일은 고사하고 수주일간의 치료로 끝 낼 수는 없는 폐결핵과 같은 질병이 더구나 복잡한 사회 생활을 하고 있는 사람과 관련돼 있는데 특수약품의 발 달만으로 그렇게 쉽게 치료 근절될 수가 없다는 것은 이 미 지적된 바가 있으며 ${ }^{2)}$ 또 우리나라에서의 결핵 현상이 여실하게 증명해 주고 있는 바이다.

소위 단기화학요법을 위주로 한 최근의 논물들 ${ }^{3 \sim 5)}$ 은 현 대적 항결핵 약제들의 강력한 효과를 제시하는데는 충분 하지만 일상임상에서 이러한 정도의 효과를 모든 환자들 에게서 얻기위해서는 여러가지의 부수적 전제조건들이 필요하다는 것을 적절하게 지적하지는 않았다고 하겠다.

본 연구의 목적은 일상적인 결핵진료소에서 얻어진 경 험을 토대로 해서 현대적 결핵치료의 혜택을 충분히 받 을 수가 있을 것이라고 또 그래야 할 초치료 폐결핵환자 들의 진료동태와 그 귀추를 알아 보고 특히 지금으로부 터 약 17 년 전에 발표된 것으로서 본 논문의 저자중의 한 사람인 이 찬세의 논문(6)과 비교해 봄으로써 그간의 변화 상을 검토해서 금후 폐결핵치료의 효과확대책을 알아보 는데 있다.

\section{재료와 연구방법}

1983년 8월 1일부터 1987년 1월 31일까지 3년 6개월 동안에 대한결핵협회 부산지부의원에서 등록치료한 초치 료환자 856명을 대상으로 했다. 여기서 초치료라고 한 것 은 자의내원이나 가족검진에 의해서 본원에서 초진단 초 치료하게된 환자 530 명, 직장, 군대, 학교등에서 검진시 에 발견된 후 본원에서 재 확인하고 치료를 한 환자 214 명, 다른 병의원, 보건소 등에서 초진단하고 한달이내의 치료를 하다가 온 112 명이다. 관찰기간은 최종일에 등록 한 환자가 적어도 10 개월 이상 관찰될 수 있도록 배려했 다. 폐엑스선 사진과 객담검사는 초진시 일과성폐염을 제 외하거나 혹은 다른 질병이 의심된 경우에 10 여일 이내 에 연거퍼서 해본 이외에는 2 3개월 간격으로 정기적으 로 반복했다.

약제감수성 검사에 관한 것은 제외했다.

1. 병세란 병변의 크기와 객담검사 결과를 아울러서 의 미한 것이다.

2. 병변분류는 과거부터 관용되고 있는 경증 (Minimal), 중등증(Moderately Advanced), 중 증 (Far Advanceed) 로 병변의 크기를 위주로 한 미 국식을 사용했다.

3. 객담검사 균양성 $(+)$, 음성 $(-)$ 는 극소수를 빼고는 배양을 기준으로 했다.

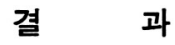

\section{1. 초치료환자의 빈도}

3 년 6 개월 간에 본원에서 본 초치료환자는 남자 544 명, 
여자 312 명 도합 856 명으로 같은 기간중의 전체 폐결핵 환자 남자 1,860 명, 여자 1,015 명 도합 2,875 명에 비해 서 $29.8 \%$ 에 해당되며 남여의 비율은 양자가 각기 63.6 $\%$ 대 $36.5 \%$ 와 $64.7 \%$ 대 $35.3 \%$ 로 비슷했다.

\section{2. 초치료환자 남여별 병세(Table 1)}

남자에선 경증이 $54.8 \%$, 중등증이 $37.3 \%$, 중증아 7.9 $\%$ 인데 여자에선 각기 $48.7 \%, 41.4 \%, 9.7 \%$ 로서 중등 증과 중증을 합해서 보면 $45.2 \%$ 대 $51 \%$ 로서 여자쪽의 병변이 약간 더 큰것 같았다. 그리고 결핵균 양성율에 있 어서도 남자는 경증에서 $15.8 \%$, 중등증에서 $50.7 \%$ 중 증에서 $69.8 \%$ 로서 전체적으로 $33.1 \%$ 인데 여자에선 각 기 $17.1 \%, 50.4 \%, 64.5 \%$ 로서 전체적으로 $35.6 \%$ 이며 더구나 균양성율이 가장 높은 중증에서 균검사 불응자가 남자에선 $14 \%$ 인데 여자에선 $22.6 \%$ 나 됐다는 것을 덧 붙여서 생각한다면 확실히 여자에선 균양성율이 좀 높았 다고 할 수가 있다. 그러므로 초치료환자에 있어서 여자 환자의 병세가 남자에서 보다 약간 중한 편이라고 할 수 있다.

\section{3. 초치료환자 병세별 연령구성(남자)(Table 2)}

초치료 폐결핵환자가 가장 많은 연령층은 병세에 관계 없이 21 30세 층이였다. 이 연령층은 경증 균양성군의 $46.8 \%$ 음성군의 $43.5 \%$ 불검자까지 합해서 경증 전체 적으로 $40 \%$ 를 차지했고 중등증에서도 각기 $33 \%, 29.8$ $\%$ 와 $32 \%$ 이고 중증에서도 $26.7 \%, 28.6 \%$ 와 $25.6 \%$ 를 차지했다. 그 다음으로 경증과 중등증에서는 병세와 관 계없이 31 40세 층이였고 중증에서는 51 60세이였는 데 31 40세 층은 다만 약간의 차이로 제 3 위를 차지했 다(전자 $20.9 \%$ 대 후자 $16.3 \%$ ). 그런데 대체적인 경향 은 최다 연령층을 정점으로 포물선형 분포를 보이면서 경 증이고 균음성인 편은 약년층에서 많고 중등증 혹은 중 증이고 균양성인 것은 노년층을 향해서 많아서 전자는 형 후자는 $~$ 형을 보였다.

\section{4. 초치료환자 병세별 연령구성(여자) (Table 3)}

여자에 있어서도 초치료환자가 가장 많은 연령층은 21 30세 층이였으며 경증 균양성군에선 $34.6 \%$, 음성

표 1. 초치료환자 남여별 병세

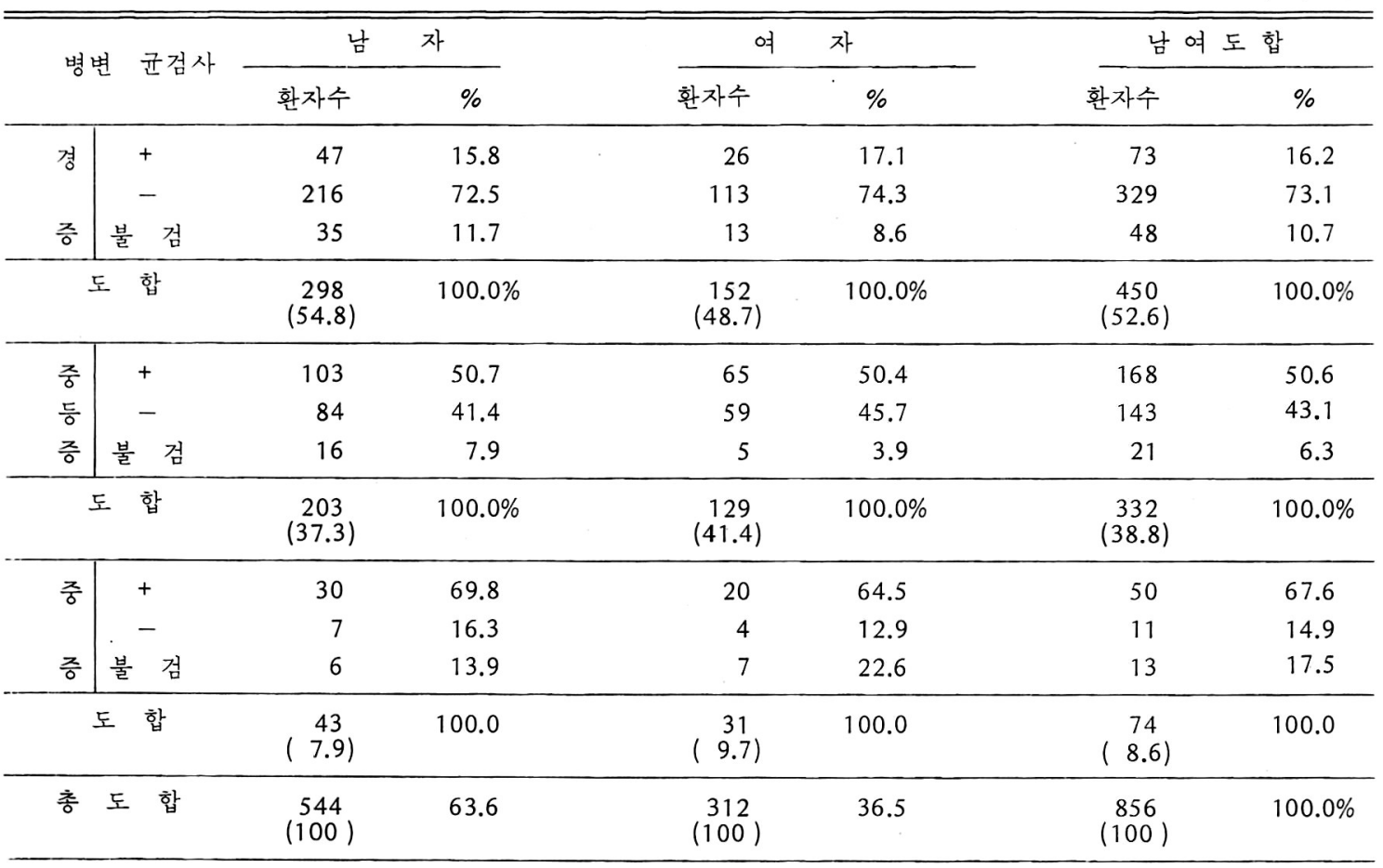


표 2. (남자) 초치료환자 병세별 연령구성 비율

( ) :\%

\begin{tabular}{|c|c|c|c|c|c|c|c|c|c|}
\hline \multicolumn{2}{|l|}{ 병변 } & 환자수 & - 10 세 & $11-20$ & $21 \cdots 30$ & $31-40$ & $41-50$ & $51-60$ & 60세+ \\
\hline \multirow[t]{2}{*}{ 경 } & $\leftarrow$ & 47 & $2(4.3)$ & $3(6.4)$ & $22(46.8)$ & $12(25.5)$ & $3(6.4)$ & $5(10.6)$ & - \\
\hline & - & 216 & $27(12.5)$ & $23(10.7)$ & $74(43.5)$ & $32(14.8)$ & $18(8.3)$ & $11(5.1)$ & $11(5.1)$ \\
\hline 증 & 불 & 35 & $23(65.7)^{*}$ & $6(17.1)$ & $3(8.6)$ & $1(2.9)$ & $1(2.9)$ & $1(2.9)$ & - \\
\hline 도 & 합 & $\begin{array}{c}298 \\
(100)\end{array}$ & $52(17.4)$ & $32(10.7)$ & 119 (39.9) & $45(15.1)$ & $22(7.4)$ & $17(5.7)$ & $11(3.7)$ \\
\hline 중 & + & 103 & $1(1.0)$ & $12(11.7)$ & $34(33.1)$ & $24(23.3)$ & $14(13.6)$ & $11(10.7)$ & $7(6.8)$ \\
\hline 등 & - & 84 & $2(2.4)$ & $17(20.2)$ & $25(29.8)$ & $16(19.5)$ & $12(14.3)$ & $7(8.3)$ & $5(6.0)$ \\
\hline 증 & 불 & 16 & - & 4 & 6 & 3 & - & 1 & 2 \\
\hline 도 & 합 & $\begin{array}{c}203 \\
(100)\end{array}$ & $3(1.5)$ & $33(16.3)$ & $65(32.0)$ & $43(21.2)$ & $26(12.8)$ & 19 ( 9.4) & $14(6.9)$ \\
\hline \multirow[t]{2}{*}{ 중 } & + & 30 & $1(3.3)$ & $3(10.0)$ & $8(26.7)$ & $5(16.7)$ & $4(13.3)$ & $6(20.0)$ & $3(10.0)$ \\
\hline & - & 7 & - & - & $2(28.6)$ & 1 & 2 & 1 & 1 \\
\hline 증 & 불 & 6 & - & - & 1 & 1 & 1 & 2 & 1 \\
\hline 도 & 합 & $\begin{array}{r}43 \\
(100)\end{array}$ & $1(2.3)$ & $3(7.0)$ & $11(25.6)$ & $7(16.3)$ & $7(16.3)$ & $9(20.9)$ & $5(11.7)$ \\
\hline \multicolumn{2}{|c|}{ 총도합 } & $\begin{array}{r}544 \\
(100)\end{array}$ & $56(10.3)$ & $68(12.5)$ & $195(35.9)$ & $95(17.5)$ & $55(10.1)$ & $45(8.3)$ & $30(5.5)$ \\
\hline
\end{tabular}

불 $=$ 객담불검사

*불검사자가 유난히 많은 이유는 병변이 경미해서 검사를 안시켰던 관계이다.

군에선 $38.1 \%$, 도합 $34.9 \%$ 를 차지했고 중등증에서는 각기 $58.5 \%$ 와 $50.9 \%$ 도합 $54.3 \%$ 를, 중증에선 각기 30 $\%$ 와 $25 \%$ 도합 $29 \%$ 였다. 제 2 위인 경증과 중등증에선 31 40세 층이고 중증에선 41 50세 층이였다.

그리고 제 3 위는 11 20세 층과 51 60세 층이 동수 로 차지했다.

대체적인 연령층분포 경향 역시 남자에서와 비슷해서 경증 균음성군은 약년층에서 중등증과 중증 균양성군은 노년층에서 많았다.

\section{5. 남여별, 병변분류별 객담검사 결과 (Table 4)}

객담검사 불응자가 남자에서 $10.5 \%$, 여자에서 $8 \%$ 전 체 도합 초치료환자의 $9.6 \%$ 이였다.

중증환자군의 수효는 남여 모두 너무 적어서 통계적으 로 큰 의의를 붙이기는 어렵지만 하여간 이들의 객담검 사 불응률은 남자 $14.0 \%$, 여자 $22.6 \%$ 로 높으며 특히 여 자의 경우는 너무 많은 감이 있다.

균양성률은 남여 모두 경증군에선 각기 $15.8 \%$ 와 17.1
$\%$ 로 저률이고 중등증에선 각기 $50.8 \%$ 와 $50.4 \%$, 중증 에서 각기 $69.8 \%$ 와 $64.5 \%$ 의 고율이었다.

\section{6. 초치료환자의 병력기간(Table 5)}

경증과 중등증군에서는 병력기간 1 3개월이 가장 많 아서 각기 $37.1 \%$ 와 $31.9 \%$ 이고 그 다음이 4 - 개월로 각기 $26 \%$ 와 $28 \%$ 이였는데 중증에서는 이들에 비해서 약 간 길어서 첫째는 4 6개월로서 $31.1 \%$, 그 다음이 $1 \sim 3$ 개월로 $24.3 \%$ 이였다.

초치료환자 전체적으로 역시 1 3개월이 $34.00 \%$ 로서 첫째이고 그 다음이 $1 \sim 6$ 개월로 $27.2 \%$, 그 다음이 1 개 월이내로 $21.5 \%$ 이였다. 그리고 초치료환자의 병력기간 으로서는 너무 길었다고 생각되지만 1 2년이 $5 \%, 2$ 년 이상이 $3.6 \%$ 나 있었다. 그런데 중증환자군은 그 환자의 수효가 모두 50명밖에 안되지만 그 중의 6 명 $(12.0 \%)$ 이 $1 \sim 2$ 년, 11 명 $(22.0 \%)$ 이 2년이상의 병력기간을 가지고 있었던 것을 보면 우선 이렇게 긴병력기간 자체의 진부 를 의심할 수도 있지만 이 환자들이 결핵병이 이렇게 진 
표 3. (여자) 초치료환자 병세별 연령구성 비율

( ) : \%

\begin{tabular}{|c|c|c|c|c|c|c|c|c|c|}
\hline \multicolumn{2}{|c|}{ 병변 } & 환자수 & $\rightarrow$ 10세 & $11-20$ & $21-30$ & $31-40$ & $41-50$ & $51-60$ & $60+$ \\
\hline \multirow[t]{2}{*}{ 경 } & + & 26 & $1(3.9)$ & $2(7.7)$ & $9(34.6)$ & $3(11.5)$ & $5(19.2)$ & $4(15.4)$ & $2(7.7)$ \\
\hline & - & 113 & $17(15.0)$ & $9(8.0)$ & $43(38.1)$ & $25(22.1)$ & $9(8.0)$ & $5(4.4)$ & $5(4.4)$ \\
\hline 증 & 불 & 13 & 8 & 3 & 1 & - & 1 & - & - \\
\hline 도 & 합 & $\begin{array}{c}152 \\
(100)\end{array}$ & $26(17.1)$ & $14(9.2)$ & $53(34.9)$ & $28(18.4)$ & $15(9.9)$ & $9(5.9)$ & $7(4.6)$ \\
\hline 중 & + & 65 & - & $4(6.2)$ & $38(58.5)$ & $13(20.0)$ & $3(4.6)$ & $1(1.5)$ & $6(9.3)$ \\
\hline 등 & - & 59 & $1(1.7)$ & $15(25.4)$ & $30(50.9)$ & $7(11.9)$ & $1(1.7)$ & $1(1.7)$ & $4(6.8)$ \\
\hline 증 & 불 & 5 & - & 1 & 2 & - & 1 & - & 1 \\
\hline 도 & 합 & $\begin{array}{c}129 \\
(100)\end{array}$ & $1(0.8)$ & $20(15.5)$ & $70(54.3)$ & $20(15.5)$ & $5(3.9)$ & $2(1.6)$ & $11(8.5)$ \\
\hline \multirow[t]{2}{*}{ 중 } & + & 20 & $1(5.0)$ & $2(10.0)$ & $6(30.0)$ & $2(10.0)$ & $5(25.0)$ & $3(15.0)$ & $1(5.0)$ \\
\hline & - & 4 & - & $1(25.0)$ & $1(25.0)$ & - & - & $1(25.0)$ & $1(25.0)$ \\
\hline 증 & 불 & 7 & 1 & 1 & 2 & 1 & 1 & - & 1 \\
\hline 도 & 합 & $\begin{array}{c}31 \\
(100)\end{array}$ & $2(6.5)$ & $4(12.9)$ & $9(29.0)$ & $3(9.7)$ & $6(19.4)$ & $4(12.9)$ & $3(9.7)$ \\
\hline \multicolumn{2}{|c|}{ 총도합 } & $\begin{array}{r}312 \\
(100) \\
\end{array}$ & $29(9.3)$ & $38(12.2)$ & $132(42.3)$ & $51(16.4)$ & $26(8.3)$ & $15(4.8)$ & $21(6.8)$ \\
\hline \multicolumn{2}{|c|}{ 남여도합 } & 856 & $85(9.9)$ & $106(12.4)$ & $327(38.2)$ & $146(17.1)$ & $81(9.5)$ & $60(7.1)$ & $51(6.0)$ \\
\hline
\end{tabular}

불 $=$ 객담불검사

표 4. 초치료환자 남여별, 병변분류별, 객담검사 결과

\begin{tabular}{|c|c|c|c|c|c|}
\hline 남여별 & 병 변 & 환 자 수 & 균 양 성 & 균 음 성 & 불 검 사 \\
\hline \multirow[t]{3}{*}{ 남 자 } & 경 증 & $298(100)$ & $47(15.8)$ & $216(72.5)$ & $35(11.7)$ \\
\hline & 중등증 & $203(100)$ & $103(50.7)$ & $84(41.4)$ & $16(7.9)$ \\
\hline & 중 증 & $43(100)$ & $30(69.8)$ & $7(16.3)$ & $6(14.0)$ \\
\hline 도 & 합 & $544(100)$ & $180(33.1)$ & $307(56.4)$ & $57(10.5)$ \\
\hline \multirow[t]{3}{*}{ 여 자 } & 경 증 & $152(100)$ & $26(17.1)$ & $113(74.3)$ & $13(8.6)$ \\
\hline & 중등증 & $129(100)$ & $65(50.4)$ & $59(45.7)$ & $5(3.9)$ \\
\hline & 중 증 & & & $4(12.9)$ & $7(22.6)$ \\
\hline 도 & 합 & $312(100)$ & $111(35.6)$ & $176(56.4)$ & $25(8.0)$ \\
\hline 총 & 합 & $856(100)$ & $291(34.0)$ & $483(56.4)$ & $82(9.6)$ \\
\hline
\end{tabular}

행될 때까지 참았던지 혹은 무관심하게 지내는 사이에 생 긴 공중보건적 문제에 대해서 새삼 개탄하지 않을 수 없 다. 타각적 자각적 증상이 경한 경증환자군의 병력 기간 이 오히려 비교적 짧아서 한달이내가 $24.2 \%$ 인데 증세가
많아서 빨리 병원을 찾을듯 한 중증군은 $6.8 \%$ 인 것은 의 아하게 느껴지지만 329 명이라는 다수를 가지고 경증의 대 부분을 차지하는 균음성군의 대부분은 각종 검진에서 무 자각 상태로 발견된 것이기 때문에 폐결핵 발견후 병원 
표 5. (남여도합) 초치료환자 병세별 병력기간 (병력기간)

\begin{tabular}{|c|c|c|c|c|c|c|c|c|}
\hline 병 분 & 변 균검사 & 환자수 & $\rightarrow 1$ 달 & 1-3달 & 4-6달 & 7-12달 & 1-2년 & 2 년 + \\
\hline \multirow[t]{2}{*}{ 경 } & + & 73 & $24(32.9)$ & $32(43.9)$ & $14(19.2)$ & $3(4.1)$ & - & - \\
\hline & - & 329 & $70(21.3)$ & $116(35.3)$ & $96(29.2)$ & $29(8.8)$ & $10(3.0)$ & $8(2.4)$ \\
\hline \multirow[t]{2}{*}{ 증 } & 불 검 & 48 & $15(31.3)$ & $19(39.6)$ & $7(14.6)$ & $5(10.4)$ & $2(4.2)$ & - \\
\hline & 도 합 & $\begin{array}{c}450 \\
(100)\end{array}$ & $109(24.2)$ & $167(37.1)$ & $117(26.0)$ & $37(8.2)$ & $12(2.7)$ & $8(1.8)$ \\
\hline 중 & + & 168 & $27(16.1)$ & $56(33.3)$ & $48(28.6)$ & $17(10.2)$ & $11(6.6)$ & $9(5.4)$ \\
\hline 등 & - & 143 & $36(25.2)$ & $42(29.4)$ & $45(31.5)$ & $6(4.2)$ & $11(7.7)$ & $3(2.1)$ \\
\hline \multirow[t]{2}{*}{ 증 } & 불 검 & 21 & $7(33.3)$ & $8(38.1)$ & - & $3(14.3)$ & $3(14.3)$ & - \\
\hline & 도 합 & $\begin{array}{c}332 \\
(100)\end{array}$ & $70(21.1)$ & 106 (31.9) & $93(28.0)$ & $26(7.8)$ & $25(7.5)$ & $12(3.6)$ \\
\hline \multirow[t]{2}{*}{ 중 } & + & 50 & $3(6.0)$ & $8(16.0)$ & $14(28.0)$ & $8(16.0)$ & $6(12.0)$ & $11(22.0)$ \\
\hline & - & 11 & $1(9.1)$ & $3(27.2)$ & $6(54.6)$ & $1(9.1)$ & - & - \\
\hline \multirow[t]{2}{*}{ 등 } & 불 검 & 13 & $1(7.7)$ & $7(53.9)$ & $3(23.1)$ & $2(15.4)$ & - & - \\
\hline & 도 합 & $\begin{array}{r}74 \\
(100) \\
\end{array}$ & $5(6.8)$ & $18(24.3)$ & $23(31.1)$ & $11(14.9)$ & $6(8.1)$ & 11 (14.9.) \\
\hline 총 & 도 합 & $\begin{array}{c}856 \\
(100)\end{array}$ & $184(21.5)$ & $291(34.0)$ & $233(27.2)$ & $74(8.6)$ & $43(5.1)$ & $31(3.6)$ \\
\hline
\end{tabular}

표 6. 〈남여도합〉〈연령군별〉초치료 폐결핵환자 발병모양(진단동기)

\begin{tabular}{|c|c|c|c|c|c|}
\hline 연 령 군 & 환자수 & 서 서 히 & $\mathrm{X}$ 선 검 진 & 객 혈 혈 담 & 급 성 폐 염 양 \\
\hline$\rightarrow 10$ 세 & 85 & $49(57.7)$ & $30(35.3)$ & - & $6(7.1)$ \\
\hline $11-20$ & 106 & $74(69.8)$ & $24(22.6)$ & $5(4.7)$ & $3(2.8)$ \\
\hline $21-30$ & 327 & $239(73.1)$ & $66(20.2)$ & $20(6.1)$ & $2(0.6)$ \\
\hline $31-40$ & 146 & $109(74.7)$ & $26(17.8)$ & $8(5.5)$ & $3(2.1)$ \\
\hline $41-50$ & 81 & $65(80.3)$ & $9(11.1)$ & $6(7.4)$ & $1(1.2)$ \\
\hline $51-60$ & 60 & $54(90.0)$ & $2(3.3)$ & $3(5.0)$ & $1(1.7)$ \\
\hline 60 세 + & 51 & $46(90.2)$ & $2(3.9)$ & $2(3.9)$ & $1(2.0)$ \\
\hline 도 & 856 & $636(74.3)$ & $159(18.6)$ & $44(5.1)$ & $17(2.0)$ \\
\hline
\end{tabular}

에 올때까지의 병력기간이 매우 짧아질 수가 있을 것이 라고 해석된다.

\section{7. 초치료환자의 발병모양(진단동기)(Table 6,7 )}

발병모양 혹은 초진단동기를 조사해 보면 전체적으로 는 서서히 발병한 것이 대부분인 $74.3 \%$ (856명 중 636 명)이고 그 다음이 여러가지 경우에서 엑스선사진검사를 받아서 발견된 것으로 $18.6 \%$ 이고 객혈 혹은 혈담이 나
와서 병원을 찾은 것이 $5.1 \%$, 급성폐염양으로 심한 기 침가래 고열 같은 증상으로 병원을 찾아온 것은 극히 적 어서 $2.0 \%$ (856명중 겨우 17 명)이였다. 이것들을 연령 군별과 병세별로 구분해 보면 상당한 특성을 볼 수가 있 었다.

연령군별로 보면 연령층이 고령화 할수록 서서히 발명 하는 것이 점증해서 10 세이하에서 $57.7 \%, 11 \sim 20$ 세군 에서 $69.8 \%$ 이던 것이 $51 \sim 60$ 세군에서 $90.0 \%$ 60세이상 
표 7. 〈남여도합〉〈병세별〉초치료 폐결핵환자 발병모양(진단동기)

( ) :\%

\begin{tabular}{|c|c|c|c|c|c|}
\hline 병 변 균 검 사 & 환자수 & 서 서 히 & $\mathrm{X}$ 선 검 진 & 객 혈 혈 담 & 급 성 폐 염 양 \\
\hline+ & 73 & $39(53.4)$ & $28(38.4)$ & $4(5.5)$ & $2(2.7)$ \\
\hline 경 증 & 329 & $234(71.1)$ & $79(24.0)$ & $12(3.7)$ & $4(1.2)$ \\
\hline 불 검 & 48 & $35(72.9)$ & $11(22.9)$ & $2(4.2)$ & - \\
\hline 도 합 & 450 & $308(68: 4)$ & $118(26.2)$ & $18(4.0)$ & $6(1.3)$ \\
\hline+ & 168 & $137(81.6)$ & $18(10.7)$ & $10(6.0)$ & $3(1.8)$ \\
\hline 중등증 & 143 & $113(79.0)$ & $16(11.2)$ & $10(7.0)$ & $4(2.8)$ \\
\hline 불 김 & 21 & $16(76.2)$ & $3(14.3)$ & $1(4.7)$ & $1(4.8)$ \\
\hline 도 합 & 332 & $266(80.1)$ & $37(11.1)$ & $21(6.3)$ & $8(2.4)$ \\
\hline+ & 50 & $42(84.0)$ & $3(6.0)$ & $3(6.0)$ & $2(4.0)$ \\
\hline 중 증 & 11 & $9(81.1)$ & $1(9.1)$ & $1(9.1)$ & - \\
\hline 불 검 & 13 & $11(84.6)$ & - & $1(7.7)$ & $1(7.7)$ \\
\hline 도 & 74 & $62(83.8)$ & $4(5.4)$ & $5(6.8)$ & $3(4.1)$ \\
\hline 총 도 합 & 856 & $636(74.3)$ & $159(18.6)$ & $44(5.1)$ & $17(2.0)$ \\
\hline
\end{tabular}

표 8. 초치료환자 남여별 병변별 병변 변화성 분류

( ) :\%

\begin{tabular}{|c|c|c|c|c|c|c|}
\hline 남여별 & 병 & 변 & 환자수 & (X) 변화성 많음 & (Y) 중 간 성 & (Z) 변화성 없음 \\
\hline \multirow{3}{*}{ 남 자 } & 경 & 증 & 298 & $71(23.8)$ & $119(39.9)$ & $108(36.2)$ \\
\hline & 중 등 & 증 & 203 & $60(29.6)$ & $121(59.6)$ & $22(10.8)$ \\
\hline & 중 & 증 & 43 & $10(23.3)$ & $21(48.8)$ & $12(27.9)$ \\
\hline 도 & 합 & & $544(100)$ & $141(25.9)$ & $261(48.0)$ & $142(26.1)$ \\
\hline \multirow{3}{*}{ 여 자 } & 경 & 증 & 152 & $41(27.0)$ & $48(31.6)$ & $63(41.5)$ \\
\hline & 중 등 & 증 & 129 & $50(38.8)$ & $60(46.5)$ & $19(14.7)$ \\
\hline & 중 & 증 & 31 & $13(41.9)$ & $11(35.5)$ & $7(22.6)$ \\
\hline 도 & 합 & & $312(100)$ & $104(33.3)$ & $119(38.1)$ & $89(28.5)$ \\
\hline 남 여 & 도 합 & & $856(100)$ & $245(28.6)$ & $380(44.4)$ & $231(27.0)$ \\
\hline
\end{tabular}

※ (X) 변화성 많음 : (1) 병력기간 6개월이내 (2) $\mathrm{X}$ 선사진 소견 신선한 인상

(3) 피로감을 위주한 결핵증상 있음.

(Z) 변화성 없음 : (1) 병력기간 2년이상 (2) $\mathrm{X}$ 선사진 소견 완고 (3) 증상 유무는 무관

(Y) $\mathrm{X}$ 와 $\mathrm{Z}$ 의 중간

에서 $90.2 \%$ 로 됐고 엑스선검진으로 발견되는 것은 이와 반대로 연령군이 노령화 될수록 적어져서 각기 $35.3 \%$ 와 $22.6 \%$ 이던 것이 $3.3 \%$ 와 $3.9 \%$ 로 되었다. 그리고 또 10 세이하의 특성으로는 객혈 혈담으로 발병된 것이 한 예
도 없고 급성폐염양으로 발병된 것이 $7.1 \%$ (85명중 6명) 으로 유독 많은 것이다.

그 다음 병세별 구분에서 보면 병변의 크기나 균 유무 와 관계없이 역시 단연 많은 것은 서서히 발병한 것이고 
그 다음이 엑스선검진, 객혈 혈담, 그리고 급성폐염 양의 순서이며 그들 각기의 비율도 전체적인 비율과 비슷했지 만 그러나 대체적으로는 중증일수록 서서히 발병하는 것 이 많아서 경증에서 $68.4 \%$ 이던 것이 중등증에서 80.1 $\%$ 중증에선 $83.8 \%$ 로 됐다. 엑스선검진 발견은 이와 반 대로 경증에서 $26.2 \%$ 이던 것이 중등증에서 $11.1 \%$, 중 증에선 $5.4 \%$ 로 현저히 감소되었다.

\section{8. 초치료환자의 폐결핵 병변의 변화성 분류} (Table 8)

현재 우리들이 상용하고 있는 엑스선사진 소견을 위주 로 하는 미국식 폐결핵 분류법은 그 병변의 크기만을 표 시하는 것으로서 유용한 점이 있기는 하지만 병변의 동 적인 면 즉 변화성은 알 수가 없는 단점이 있다. 이 찬 세가 주장하는 폐결핵병변의 변화성 분류법ㄱ)은 초진 시 폐결핵의 동적성질 (Dynamism)을 판정하므로써 치료계 획과 예후 추정을 할 수 있도록 하자는 것을 목적으로 한 것이다. 세가지의 참고조건 즉 병력기간과 엑스선사진의 인상 그리고 결핵의 대표증상으로써 만성피로감 유무를 종합해서 다음에 세가지로 분류한다.

(1) 변화성이 많은것 부호 $(\times)$, 이것은 병력기간이 6 개월 이내이고 엑스선사진의 인상이 신선하고 만성피로감의
호소가 많은 것이다. (2) 변화성이 없는 것, 부호 $(Z)$, 이 것은 병력기간이 2 년이상, 엑스선사진의 인상이 진구하 고 만성피로감 별무인것, (3) 중간상태 부호(Y), (1)과 (2) 의 중간인 것, 심한 기침, 가래, 객혈, 고열 등과 같은 일과성인 증상이나 전신쇠약과 같은 중증증상은 기준 참 고사항이 아니다. 이상의 분류법을 이용해서 본 환자들 을 구분해 보면 변화성이 많은 것이 $28.62 \%$, 변화성이 없는 것이 $26.99 \%$, 중간상태가 $44.39 \%$ 이어서 적절한 치료에 의해서 균음성화와 동시에 병변의 상당한 치유가 예상되는 것이 $70 \%$ 이상이라는 것을 알 수가 있다. 그런 데 남여모두 경증환자에선 변화성이 없는 것이 현저히 많 아서 각기 $36.24 \%$ 와 $41.45 \%$ 이고 중등증에선 각기 $10.84 \%$ 와 $14.73 \%$, 중증에선 각기 $27.91 \%$ 와 $22.58 \%$ 이었다. 이러한 점이 있기 때문에 병변의 변화성 분류법 을 첨가할 필요성을 알 수 있다.

\section{9. 초치료환자의 본원 치료기간 (Table 9)}

전체적으로 볼 때 3 회이내의 아주 짧은 진료 즉 진단 확정 정도로만 진료를 끝낸 것이 $29.1 \%$ 나 되었는데 경 증군에서 $28.2 \%$ 중등증군에서 $29.5 \%$, 중증군에서 32.4 $\%$ 로서 그 차이는 많지 않으나 증상이 많을 것으로 추측 되는 중증쪽으로 가면서 오히려 이러한 조기중단자가 더

표 9. (남여도합) 초치료환자 병변별 본원치료기간

(본원치료기간)

$(\quad): \%$

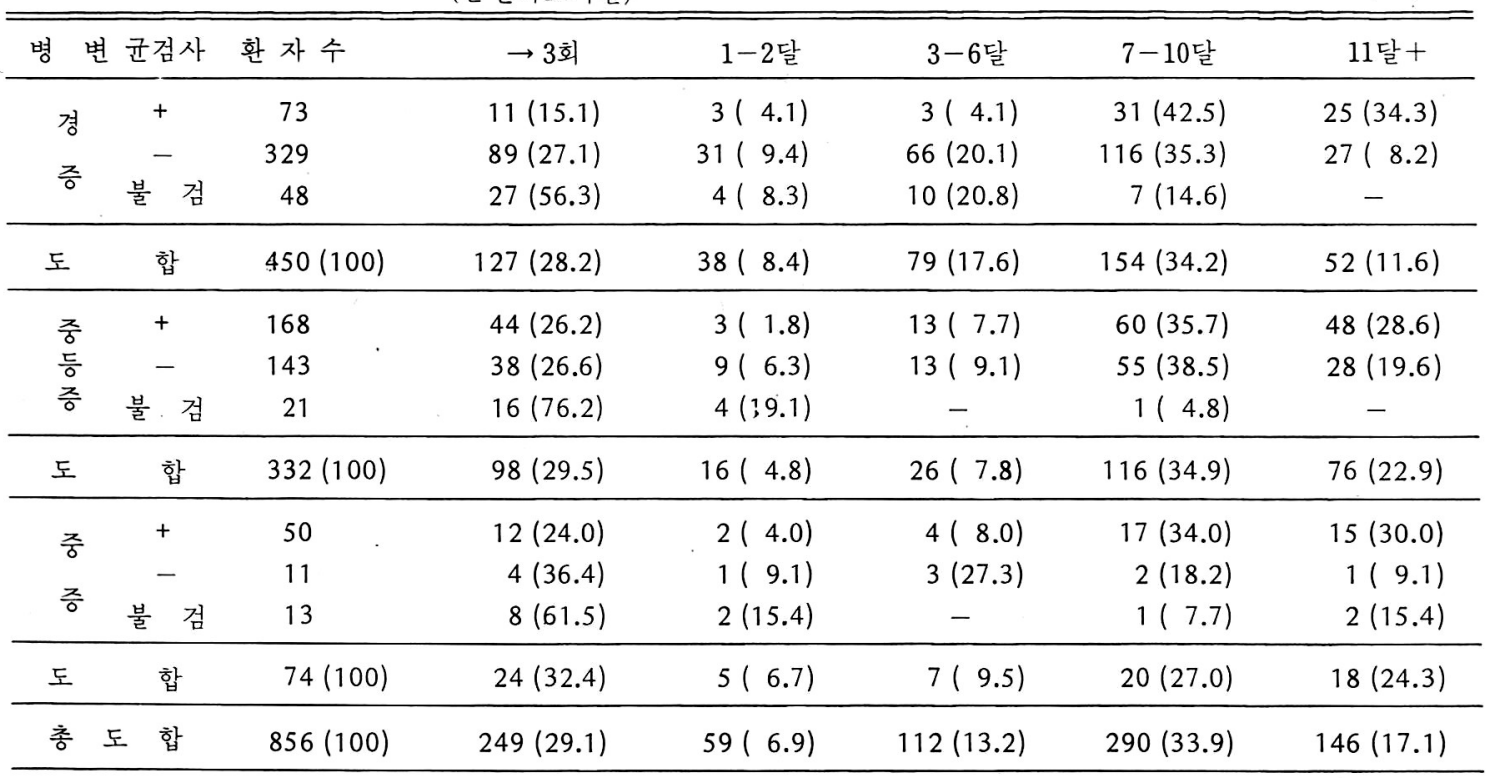


많았다. 이들 중에서 균양성자군 만을 따로 빼서 봐도 경 증군에선 $15.1 \%$ 중등증군에선 $26.2 \%$, 중증군에서 24.0 $\%$ 로 비슷한 양상을 보였다. 치료기간이 7 10개월인 것 이 가장 많아서 전체적으로, $33.9 \%$ 인데 여기서도 특기 할 것은 경증균양성군에서는 $42.5 \%$ 인데 중등증양성군 에선 $35.7 \%$ 중증양성군에선 $34.0 \%$ 로 중증일수록 오히 려 장기간 치료자 비율이 적어지는 듯한 인상이다. 치료 기간 11 개월 이상인 것 역시도 균양성군 만을 보면 경증 군에서는 $34.3 \%$ 인데 중등증군에선 $28.6 \%$, 중증군에선 $30.0 \%$ 로서 먼저와 비슷한 인상을 보인다.

대체적으로 보아서 균음성자들에서 3 회 이내의 진료로 서 진단만 확인하는 것으로 끝낼 수 있음은 짐작할 수 있 으며 특히 경증군에서 객담불검사군의 $56.3 \%$ 가 이렇게 끝낸 것은 대부분이 비 활동성 판정을 받았기 때문이므 로 문제가 없으나 치료 효과를 기대할 수 있는 치료기간 으로 생각되는 7 개월이상 치료계속자는 전체적으로 51.0 $\%$ 이고 균양성자만으로 보면 경증군에서 $77.7 \%$ 로 오히 려 가장 많고 중등증군에선 $64.3 \%$ 중증에서는 $64.0 \%$ 로 약간씩 감소되는 경향을 보였다는 것은 일반치료 상 식으로 봐서 의외이다. 치료기간 $3 \sim 6$ 개월인 것은 경증
군에서 $17.6 \%$ 중등증군 $7.8 \%$, 중증군에선 $9.5 \%$ 이었 다.

치료기간 1 2개월인 것은 전체적으로 각군에 있어서 가장 적어서 경증군에서 $8.4 \%$ 중등증군에서 $4.8 \%$ 중 증군에서 $6.8 \%$ 전체적으로 $6.9 \%$ 이었으므로 조기탈락 자는 대다수가 3 회이내의 진료로 끝냈다고 하겠다.

\section{0. 초치료환자의 치료결과}

\section{(10-1) 3 6개월에 종결한 환자들}

(Table 10 (1))

3 6개월에서 치료종결된 환자들은 도합 102명인데 그 과반수인 66 명이 경증 균음성자들로서 이들의 대부분인 56 명 $(84.9 \%)$ 은 비활동성으로 판정되었다. 경증 균양성 자 3 명은 전원 음전되었고 1 명은 병변의 현저한 경괘를 보였다. 경증 음성자 66 명중 1 명 $(1.5 \%)$ 이 균양성으로 되 었다.

중등증 균양성자 13 명중 10 명 (76.9\%)은 균음전되었 고 7 명 $(53.9 \%)$ 은 비활동성으로 되고 3 명 $(23.2 \%)$ 은 병 변의 현저한 경쾌를 보였다. 중등증 균음성자 13 명 중에 서 10 명 $(76.9 \%)$ 은 비활동성으로 되고 1 명 $(7.7 \%)$ 은 병

표 10-(1) 초치료환자의 치료결과 〈3-6개월〉에 끝낸 환자들

( ) :\%

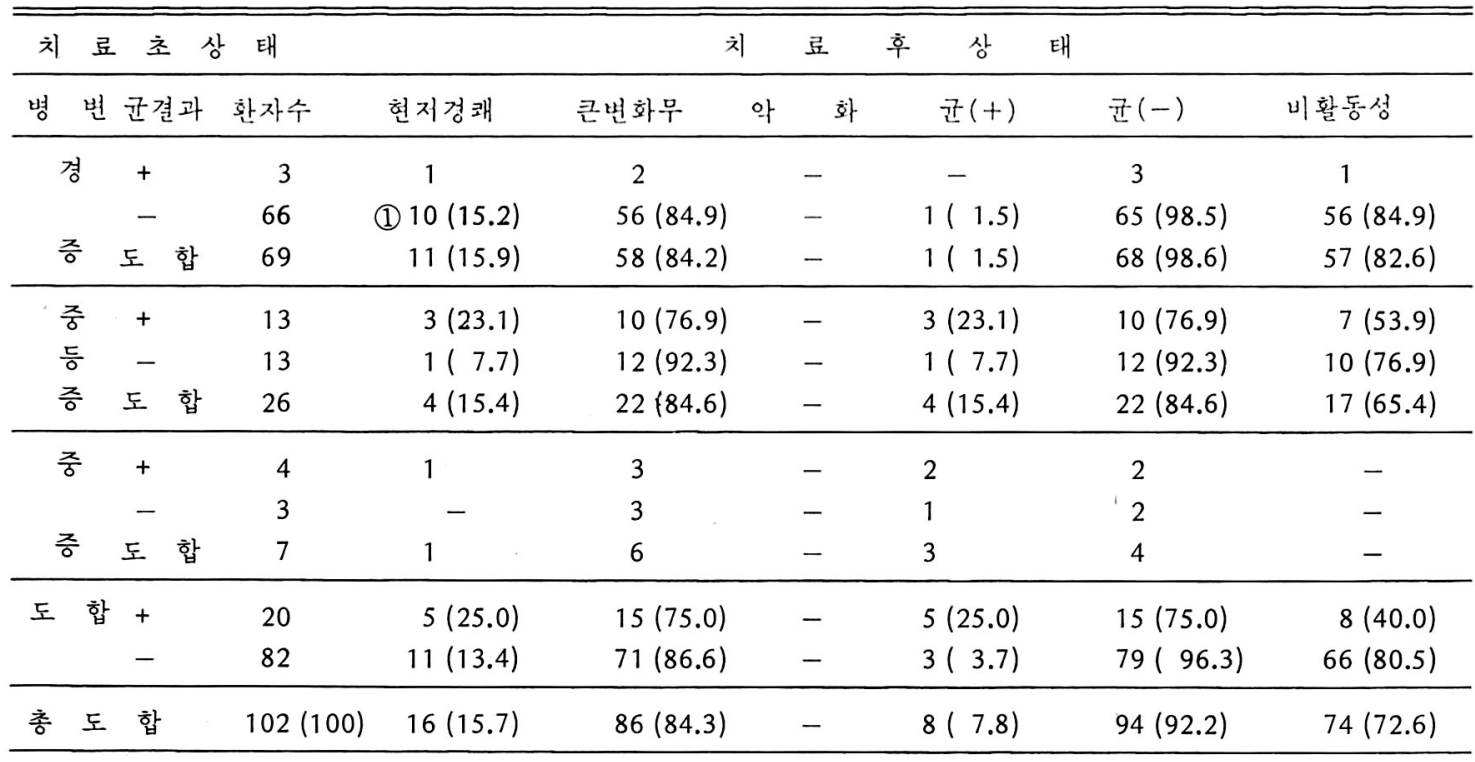

$※$ 현저경쾌 $=$ 병변분류를 바꿀 정도로 현저한 경쾌 큰변화무 $=$ 약간의 경쾌도 포함

(1) = 현저한 경쾌중 1 예는 병변이 홉수 소실 치유된 것. 
변의 현저한 경쾌를 보였는데 1 명 $(7.7 \%)$ 은 균양성이 되 었다.

중증은 도합 7 명뿐인데 균양성자 4 명중 2 명이 음전되 고 1 명에서 병변의 현저한 경쾌를 보였다. 음성자 3 명중 에서는 1 명이 양전되었다.

이상에서 보면 3 6개월로 치료종결로 한 환자들이라 도 균음전율이 $75.0 \%$ 이고 병변의 현저한 경쾌율이 15.7 $\%$ 이었으며 균양전율은 $3.7 \%$ 뿐이며 병변의 악화는 없었 다는 것을 알 수 있다.

(10-2) 7 10개월에 종결한 환자들 (Table 10 (2))

치료기간 7 10개월에서 종결된 환자들은 도합 281명 인데 총체적으로 봐서 비활동성으로 된것이 267 명 (95.0 $\%)$ 이고 병변이 현저히 경쾌된 것이 135 명 $(47.4 \%)$ 인데 이중 3 명 $(1.2 \%)$ 은 병변이 흡수 소실돼서 완전치유라고 할 정도이다.

병변이 악화된 것은 6 명 $(2.1 \%)$ 이고 균이 양성인 것도 6 명 $(2.1 \%)$ 뿐이었다. 균양성자 108 명의 균음전율은 97.2 $\%$ 이었고 균음성자 105 명의 균양전율은 $1.7 \%$ 이었다.

경증군에서 균양성자 31 명은 전원인 $100 \%$ 가 균음전
과 비활동성으로 되었고 병변의 현저 경쾌가 $32.3 \%$ 이었 다.

균음성자 116 명 중에선 균양전과 병변악화가 각각 1.7 $\%$ (2명)씩이고 비활동성으로 된 것이 $97.4 \%$ 이었다.

중등증군에서 균양성자 60 명중에선 균음전 $96.7 \%$, 비 활동성 $93.3 \%$ 로 되었고 병변의 현저경쾌가 $63.3 \%$ 이었 다. 병변의 악화와 균양성계속이 각각 $3.3 \%$ (2명)씩이었 다. 균음성자 55 명중에선 비활동성으로 된 것이 $96.4 \%$, 병변의 현저 경쾌가 $72.7 \%$ 이고 균이 양전된 것과 병변 이 악화된 것이 각각 $1.8 \%$ (1명)씩이었다.

중증군에서 균양성자 17 명중에선 12 명 $70.6 \%$ 가 비활 동성으로 되었고 균음전율은 $94.1 \%$ (16명)이었다. 병변 의 악화와 균양성계속자가 각각 $5.9 \%$ (1명)씩이다. 균음 성자는 겨우 2 명뿐인데 모두 비활동성으로 됐다.

(10-3) 11 개월이상 치료한 환자들(Table 10 (3))

치료기간 11 개월 이상인 환자들은 도합 144 명인데 총 체적으로 봐서 비활동성으로 된 것이 $91.0 \%$ 이고 병변이 현저히 경쾌된 것이 $31.9 \%$ 인데 이 중 2 명 $(1.4 \%)$ 은 병 변이 흡수 소실돼서 완전 치유라고 할 수 있을 정도이다.

표 10-(2) 초치료환자의 치료결과 $\langle 7-10$ 개 월〉에 끝낸 환자들

$(\quad): \%$

\begin{tabular}{|c|c|c|c|c|c|c|c|c|c|c|c|}
\hline 치 & 료 Z & 상 & 태 & & & 치 & 료 & 후 & 상 & & \\
\hline 병 & \multicolumn{2}{|c|}{ 변 균결과 } & 환자수 & 현저경쾌 & 큰변화무 & 악 & \multicolumn{2}{|l|}{ 화 } & 균 $(+)$ & 균 $(-)$ & 비활동성 \\
\hline & + & & 31 & (1) $10(32.3)$ & $21(67.7)$ & & - & & - & $31(100)$ & $31(100)$ \\
\hline \multirow[t]{2}{*}{ 경 } & 증 & & 116 & (1) $42(36.2)$ & $72(62.1)$ & \multicolumn{2}{|c|}{$2(1.7)$} & & $2(1.7)$ & $114(98.3)$ & $113(97.4)$ \\
\hline & 도 & 합 & 147 & $52(35.4)$ & $93(63.3)$ & \multicolumn{2}{|c|}{$2(1.4)$} & & $2(1.4)$ & $145(98.6)$ & $144(98.0)$ \\
\hline \multirow{3}{*}{ 중등증 } & + & & 60 & (1) $38(63.3)$ & $20(33.3)$ & \multicolumn{3}{|c|}{$2(3.3)$} & $2(3.3)$ & $58(96.7)$ & $56(93.3)$ \\
\hline & 증 - & & 55 & $40(72.7)$ & $14(25.5)$ & \multicolumn{3}{|c|}{$1(1.8)$} & $1(1.8)$ & $54(98.2)$ & $53(96.4)$ \\
\hline & 도 & 합 & 115 & $78(67.8)$ & $34(29.6)$ & \multicolumn{3}{|c|}{$3(2.6)$} & $3(2.6)$ & $112(97.4)$ & $109(94.8)$ \\
\hline \multirow{3}{*}{ 중 } & \multirow{3}{*}{ 증 } & & 17 & $5(29.4)$ & $11(64.7)$ & \multicolumn{3}{|c|}{$1(5.9)$} & $1(5.9)$ & $16(94.1)$ & $12(70.6)$ \\
\hline & & & 2 & - & 2 & \multicolumn{3}{|c|}{-} & - & 2 & $2(100)$ \\
\hline & & 합 & 19 & $5(26.3)$ & $13(68.4)$ & \multicolumn{3}{|c|}{$1(5.3)$} & $1(5.3)$ & $18(94.7)$ & $14(74.7)$ \\
\hline \multirow[b]{2}{*}{ 도 } & + & & 108 & $53(49.1)$ & $52(48.2)$ & \multicolumn{3}{|c|}{$3(2.8)$} & $3(2.8)$ & $105(97.2)$ & $99(91.7)$ \\
\hline & 합 - & & 173 & $82(47.4)$ & $88(50.9)$ & \multicolumn{3}{|c|}{$3(1.7)$} & $3(1.7)$ & $170(98.3)$ & $168(97.1)$ \\
\hline 총도 & 합 & & $\begin{array}{c}281 \\
(100)\end{array}$ & $135(48.0)$ & $140(49.8)$ & & $(2.1)$ & & $6(2.1)$ & $275(97.9)$ & $267(95.0)$ \\
\hline
\end{tabular}

병변이 홉수 소실돼서 완전 치유된 것 3 예 $(1.1 \%)$

※ 1. 현저경쾌 $=$ 병변분류를 바꿀정도로 현저한 경쾌

2. 큰변화무 $=$ 약간의 경쾌도 포함

3. (1) = 현저한 경쾌중 1 예는 병변의 홉수 소실 치유된 것. 
표 10-(3) 초치료환자의 치료결과〈11개월이상〉 치료한 환자들

( ) :\%

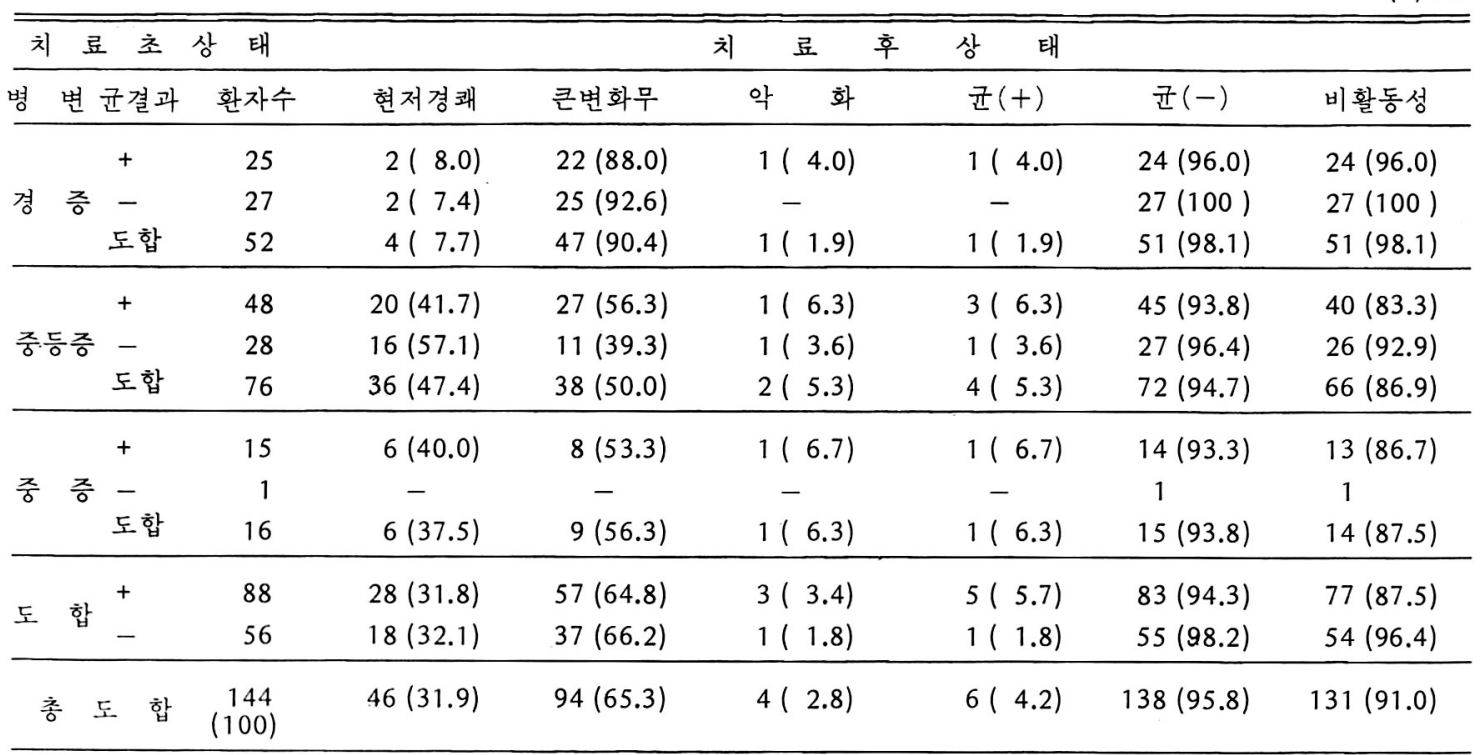

병변이 흡수 소실돼서 완전 치유된 것 2 예 $(1.4 \%)$

※ 현저경괘 $=$ 병변분류를 바꿀정도로 현저한 경쾌

큰변화무 $=$ 약간의 경쾌도 포함

(2) = 현저경쾌중 2 예는 병변의 홈수소실 치유된 것

균음전실패자는 $4.2 \%$ (6명), 병변악화자는 $2.8 \%$ (4명) 이었다.

균양성자 88 명중에선 $87.5 \%$ 가 비활동성으로 되고 병 변의 현저 경쾌가 $31.8 \%$, 악화가 $3.4 \%$ 이고 균음전실 패가 $5.7 \%$ 이었다. 균음성자가 56 명중에선 $96.4 \%$ 가 비 활동성으로 되고 병변의 현저 경쾌가 $32.1 \%$, 악화가 1.8 $\%$ 이고 균양전이 $1.8 \%$ 이었다.

경중군에선 균양성자 25 명중에서 $96 \%$ 가 비활동성으 로 되고 병변의 현저경쾌는 $8.0 \%$ 뿐이고 $4.0 \%$ 는 악화 되고 균음전실패도 $4.0 \%$ 이었다.

균음성자 27 명은 전원 $100 \%$ 가 비활동성으로 됬고 그 중 2 명 $(7.1 \%)$ 은 병변이 흡수 소실되었으므로 결핵진단 이 문제될 수도 있을 것이다.

중등증군에서 균양성자 48 명은 $83.3 \%$ 가 비활동성으 로 되고 병변의 현저한 경쾌가 $41.7 \%$, 악화가 $2.1 \%$, 균 음전실패가 $6.3 \%$ 이었다. 균음성자 28 명은 $92.9 \%$ 가 비 활동성으로 되고 병변의 현저한 경쾌가 $57.1 \%$, 악화가 $3.6 \%$ 이었다.

중증군에서 균양성자가 15 명은 $86.7 \%$ 가 비활동성으
로 되고 병변의 현저경쾌가 $40.0 \%$, 악화가 $6.7 \%$ 이고 균음전실패가 $6.7 \%$ 이었다. 균음성자는 1 명뿐이었는데 그대로 비활동성으로 됐다.

(10-4) 3 개월이상 치료환자 도합(Table 10 (4))

치료기간 3 6개월인 환자 102명, 7 10개월인 환자 281 명, 11 개월이상인 환자 144 명 도합 527 명은 초치료 환자 충등록자중의 $61.6 \%$ 에 해당되는데 이들의 치료종 결시에 상태를 도합해 보면 비활동성이 $89.6 \%$ 이고 균양 성 $3.8 \%$, 병변악화 된 것이 $1.9 \%$ 이며 병변이 현저히 경 쾌된 것이 $37.4 \%$ 이다.

균양성자가 216 명에서 보면 균음전율이 $94.0 \%$ 이고 균 음전실패자가 $6.0 \%$, 비활동성으로된 것이 $85.2 \%$ 인데 병변의 현저경쾌가 $39.8 \%$ 이었다.

균음성자 311 명을 보면 비활동성으로 된 것은 $92.6 \%$ 로서 균양성자보다 약간 많았으나 병변의 현저경쾌는 $35.7 \%$ 로서 오히려 좀 적었으며 균양전율은 $2.3 \%$, 병변 의 악화율은 $1.3 \%$ 이었다.

\section{〈결핵치료 처방〉}

초치료환자의 결핵치료 처방은 일정하게 사전에 결정 
표 10-(4) 초치료환자 치료결과 3개월이상 치료자 도합

(1):\%

\begin{tabular}{|c|c|c|c|c|c|c|c|c|}
\hline \multicolumn{3}{|c|}{ 치료초상태 } & \multirow{2}{*}{$\begin{array}{c}\text { 치 } \\
\text { 변 화무 }\end{array}$} & \multicolumn{2}{|c|}{ 후 상 } & \multicolumn{3}{|l|}{ 태 } \\
\hline 균검사결고 & 환자수 & 현저경 쾌 & & 악 & 화 & 균 $(+)$ & 균 $(-)$ & 비활동성 \\
\hline$(+)$ & $216(100)$ & $86(39.8)$ & $124(57.4)$ & & 2.8) & $13(6.0)$ & $203(94.0)$ & $184(85.2)$ \\
\hline$(-)$ & $311(100)$ & $111(35.7)$ & $196(63.0)$ & 4 & 1.3) & $7(2.3)$ & $304(97.8)$ & $288(92.6)$ \\
\hline 도 합 & $527(100)$ & $197(37.4)$ & $320(60.7)$ & 10 & 1.9) & $20(3.8)$ & $507(96.2)$ & $472(89.6)$ \\
\hline
\end{tabular}

※ 1. 3 개월 이상 치료한 환자 527 명은 초치료 총등록환자 856 명의 $61.6 \%$ 임.

2. 균양성자 216 명은 양성자 총수 291 명의 $74.2 \%$ 균음성자 311 명은 음성자총수 483 명의 $64.4 \%$ 에 해당함.

된 것이 아니고 상식적인 범위에서 개별적으로 실시됬으 나 변화성이 많고 균양성인 것은 강력한 다자처방을 하 고 변화성이 적고 균음성인 것은 두가지의 복합치료처방 을 그리고 병변이 아주 경미하고 혹은 처음부터 비활동 성인 듯한 경우엔 $1 \mathrm{NH}$ 단일처방을 하는 정도의 원칙이 유지되었다.

$\mathrm{SM}$ 과 $\mathrm{KM}$ 그리고 $\mathrm{TUM}$ (쓰베락진) 과 같은 주사제는 극소수에서 사용됬을 뿐이다.

치료약제 처방빈도를 대략 집계해 보면 다음과 같다. 균양성자에 대해서는

1) $\mathrm{RFP}+1 \mathrm{NH}+\mathrm{EMB}$ $54.8 \%$

2) $(1)+P Z$ $24.8 \%$

3) (2) $+\mathrm{CS}$ $12.3 \%$

4) $\mathrm{RFP}+1 \mathrm{NH}+\mathrm{PZ}$ $6.1 \%$

5) (3) + PAS $2.0 \%$

$100 \%$

균음성자에 대해서는

1) $\mathrm{RFP}+1 \mathrm{NH}$ $42.1 \%$

2) $1 \mathrm{NH}+\mathrm{PAS}$ $40.0 \%$

3) $1 \mathrm{NH}$ 단일 $18.0 \%$

$100 \%$

$\begin{array}{cc}\text { ※ } \mathrm{RFP}=\text { 리팜피신, } & 1 \mathrm{NH}=\text { 아이소나이짓드 } \\ \mathrm{EMB}=\text { 에담부톨 } & \mathrm{PZ}=\text { 피라지나마이드 } \\ \mathrm{CS}=\text { 싸이클로셀린 } & \text { 혹은 피아졸리나 } \\ \text { 혹은 테리발리딘 } & \begin{array}{c}\mathrm{PAS} \\ \text { 과립파스 } \\ \end{array} \\ \text { 혹은 하이드라파스 }\end{array}$

\section{1. 가족내 결핵병력 (Table 11-(1), (2))}

가족내 결핵병력은 조사기록이 좀 불비하고 누가 가족 내 전판원의 역할을 했다는 것을 규명하지는 못했지만 등 록한 초치료환자를 중심으로 가족관계별로 보면 결핵병 력이 인정된 것이 총환자 856 명의 $11.1 \%$ 인 95 명인데 이 중에서 가장 많은 것이 아버지로서 현재 치료중인 것이 15 명, 과거력이 있는 것이 7 명, 결핵으로 사망한 것이 5 명, 도합 27 명 $(28.4 \%)$ 이었다. 그 다음은 형 제로서 25.3 $\%$, 그 다음이 어머니로서 $21.1 \%$ 이었다. 부부는 아내가 4 명, 남편이 3 명으로 도합 7 명 $(7.4 \%)$ 이었다. 전체적으 로 현재 치료중인 64 명 $(67.4 \%)$ 과거력 인정이 22 명 (23.5 $\%$ ), 결핵사망력이 9 명 $(9.8 \%)$ 이었다.

초치료등록환자의 남여별, 병세별로 가족력의 빈도를 보면 남자환자 544 명중 가족력 양성자수는 63 명 (11.6\%) 이고 여자환자 312 명중 가족력 양성자 수는 32 명 10.3 $\%$ 이고 남여도합해서는 $11.1 \%$ 이었다.

초치료환자의 병세별로 가족력 발견빈도를 보면 남자 나 여자나 간에 경증균음성군에서 제일 많아서 각각 63 명중 35 명 $(55.6 \%)$ 과 32 명중의 13 명 $(40.6 \%)$ 이고 그 다 음이 중등증 균음성군에서이다.

남여 도합해서 중증 균양성군과 경증균양성군에서는 각각 5 명 $(5.3 \%)$ 이므로 전체적으로 조치료환자가 균양성 인 경우는 가족결핵력이 32 명 $(33.7 \%)$ 인데 비해서 균음 성군에서 63 명 $(66.3 \%)$ 으로 많았다. 이것은 균음성인 경 증 초치료환자의 등록이 본 연구대상에서 많은 비율을 차 지하고 있기 때문이라고 하겠다. 
표 11-(1) 초치료환자 중심 가족내 결핵병력

\begin{tabular}{|c|c|c|c|c|c|c|}
\hline 가 & 족 관 구 & 계 & 현 재 치 료 중 & 과 거 력 & 결 핵 사 망 & 도 \\
\hline 부 & 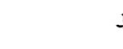 & 부 & $6(9.4)$ & $1(4.6)$ & - & $7(7.4)$ \\
\hline 어 & 머 2 & 4 & $13(20.3)$ & $6(27.3)$ & $1(11.1)$ & $20(21.4)$ \\
\hline 아 & 버 & 지 & $15(23.4)$ & $7(31.8)$ & $5(55.6)$ & $27(28.1)$ \\
\hline 조 & 부 & 모 & $2(3.1)$ & - & $2(22.2)$ & $4(4: 2)$ \\
\hline 형 & 제 자 & 매 & $17(26.6)$ & $6(27.3)$ & $1(11.1)$ & $24(25.3)$ \\
\hline 자 & & 식 & $6(9.4)$ & - & - & $6(6.3)$ \\
\hline 고 & 모, 삼 & 촌 & $4(6.3)$ & $1(4.6)$ & - & $5(5.3)$ \\
\hline 며 & 느 & 리 & $1(1.6)$ & - & - & $1(1.1)$ \\
\hline 시 & 부 & 모 & - & $1(4.6)$ & - & $1(1.1)$ \\
\hline 도 & & 합 & $\begin{array}{c}64(100) \\
(67.4)\end{array}$ & $\begin{array}{c}22(100) \\
(23.2)\end{array}$ & $\begin{array}{l}9(100) \\
(9.5)\end{array}$ & $95(100)$ \\
\hline
\end{tabular}

표 11-(2) 초치료환자 병세별 남여별 가족력

$(\quad): \%$

\begin{tabular}{|c|c|c|c|c|c|c|c|c|}
\hline \multirow{2}{*}{ 남여 별 } & \multirow{2}{*}{ 환자수 } & \multirow{2}{*}{ 가족력 (+) } & \multicolumn{2}{|l|}{ 경 } & \multirow{2}{*}{ 중 등 } & 증 & \multirow{2}{*}{$\frac{\text { 중 }}{(+)}$} & 증 \\
\hline & & & $(+)$ & $(-)$ & & $(-)$ & & $(-)$ \\
\hline 남 자 & 544 & $\begin{array}{c}63(100) \\
(11.6)\end{array}$ & $4(6.3)$ & 论35(55.6) & $14(22.2)$ & $8(12.7)$ & $2(3.2)$ & - \\
\hline 여 자 & 312 & $\begin{array}{c}32(100) \\
(10.3)\end{array}$ & $1(3.1)$ & $\odot 13(40.6)$ & $8(25.0)$ & $6(18.8)$ & $3(9.4)$ & $1(3.1)$ \\
\hline 도 합 & 856 & $\begin{array}{c}95(100) \\
(11.1)\end{array}$ & $5(5.3)$ & $48(50.5)$ & $22(23.2)$ & $14(14.7)$ & $5(5.3)$ & $1(1.1)$ \\
\hline
\end{tabular}

노 : 한 집안에 결핵환자가 3 명과 4 명 있는 것 각 1 예씩 있음.

$\odot$ : 한 집안에 결핵환자 3 명 있는 것 1 예 있음

\section{고 안}

본 저자중의 한사람인 이찬세(6)가 지난 1970년에 발표 한 결과이와 본 연구결과를 비교하는데는 우선 그 대상환 자의 수효에 있어서 123 명대 856 명이라는 큰 차이가 있 고 또 그 조사장소가 다르다는 점보다도 더 중요한 것으 로 부분적이나마 의료보험제의 도입과 결핵치료제의 발 전보급 그리고 그간 17 년동안이나 더 축적된 $\mathrm{BCG}$ 예방 접종의 효과와 일반국민들의 보건지식의 향상등을 지적 하지 않을 수가 없다.

우선 전체 폐결핵환자에 대한 초치료환자의 비율이 본 건에서는 $29.8 \%$ 이고 전자에서는 $13.3 \%$ 이며 남여의 비
율에 있어서도 본건에서는 약 1.7 대 1 인데 전자이에선 4 대 1 이고 1985 년도 전국 실태조사 $\left.{ }^{12}\right)$ 에서의 결핵유병률의 남여의 비율은 1.8 대 1 이고 1965 년도의 것은 2 대 1 이었 던 점으로 봐서 초치료환자 특히 여자환자들에 대한 결 핵진료소의 문턱이 많이 낮아졌다고 할 수가 있다.

병변분류별 빈도의 차이를 보면 전자6)에서는 경증이 $39.0 \%$, 중등증이 $56.1 \%$, 중증이 $4.9 \%$ 이었는데 본건 에는 각기 $54.8 \%, 37.3 \%$ 와 $7.90 \%$ 로서 경증이 현저하 게 많았다. 그런데 1965년도 전국실태조사 ${ }^{12)}$ 에서 유병자 의 분류 빈도는 경증이 $64.7 \%$, 중등증이 $23.5 \%$, 중증 이 $11.8 \%$ 이고 1985 년도에선 각기 $50.0 \%, 40.91 \%$, $10.0 \%$ 인 것을 고려한다면 초치료환자 중에서도 특히 경 증환자들에 대한 결핵진료소의 문턱이 매우 낮아졌다는 
것이고 치료효과의 극대화를 위해서 절대로 필요한 조기 치료가 많이 실천되고 있다고 볼 수 있을 것이다.

초치료환자의 연령층 구성비율을 보면 남여 도합해서 21 30세층이 월등하게 많아서 $38.2 \%$ 로 첫째이고 그 다 음이 31 40세층으로 $17.1 \%$ 이었는데 전자6)에서도 비슷 하게 $16 \sim 30$ 세층이 $52.0 \%$ 로 첫째이고 그 다음이 $31 \sim 45$ 세층으로 $30.9 \%$ 이었다. 그런데 전국실태조사 ${ }^{12)}$ 에서는 1985년이나 1965년에서나 비슷하게 거의 일직선으로 고 령층을 향해서 계속 상승경향을 보이므로 결국 17년전이 나 지금이나 고령층들에게는 아직도 병원문턱이 높다고 하겠다.

객담검사 결과를 보면 전체적으로 균양성자가 $34.0 \%$ 이고 불검사자는 $9.6 \%$ 인데 전자6)에서는 각기 $57.7 \%$ 와 $20.3 \%$ 로 양성율과 불검사율이 모두 높다. 이것은 최근 의 환자들이 더 협조적이기도 하다고 할 수 있지만 또 중 요한 원인은 경증환자가 현저하게 많은 비율을 차지하기 때문이라는 점을 지적할 수가 있다.

초치료환자들의 병세별 병력기간을 보면 균양성자들에 있어서는 병변이 클수록 병력기간이 매우 길어서 경증양 성군은 3 개월이내가 $76.7 \%$ 나 되는 데 중증에서는 겨우 $22.0 \%$ 뿐이다. 이것은 경증이 중증으로 발전되기까지의 긴 기간이 필요하다는 것을 의미하지만 비교적 자각증세 가 많을 중증환자들이 어째서 초진단이 그렇게 늦었느냐 하는 것을 생각해 보지 않을 수가 없다. 그래서 병력기 간이 7 개월이상인 중등증 균양성자 37 명과 중증 25 명을 따로 조사해 본 즉 그들 전부가 의료보험이 없는 경제적 으로 하층계급 사람들이였으며 남여별 혹은 연령별 특성 은 인정되지 않았돠. 이러한 환자들은 보건소의 무료진 료를 일찍 이용할 수 있어야 할터인데 그렇지 못한 것은 결국 이러한 계층들의 무지와 서서히 진행되는 폐결핵의 만성적 증상 때문이라고 해석된다.

초치료 폐결핵환자들의 결핵병변의 변화성분류를 보면 남여간이나 병변의 경중에 따른 특별한 차이는 없으며 전 체적으로 변화성이 많은 것이 $28.6 \%$, 없는 것이 27.0 $\%$, 중간성이 $44.4 \%$ 인데 전자6)의 것에서는 각기 58.5 $\%, 15.4 \%, 26.0 \%$ 로서 변화성이 많은 것이 현저히 많 고 변화성이 적은 것과 중간성이 모두 현저히 적었다. 이 것은 물론 분류 적용자체의 주관적차이도 있겠지만 이보 다는 오히려 무증상 균음성인 경증환자가 이번것에는 더 많이 포함됐다는 점도 생각해야 한다. 그러나 또 한쪽으 로 보면 하여간 치료가 필요한 사람들에 있어서 조기진
단이 아직도 많이 모자르다고 할 수 있다.

초치료폐결핵 환자들의 발병모양 혹은 진단동기를 구 분분류 한 것에서 10 세이하군에서와 경증균 양성군에선 엑스선사진검사에서 폐결핵이 발견된 것이 각기 $35.3 \%$ 와 $38.4 \%$ 인 것을 보면 가족 검진이나 각종 신체검사에 서의 엑스선사진검진의 유용성이 매우 크다고 하겠다. 그 런데 전체적으로 보면 이번 것에서 서서히 발병한 것이 $74.3 \%$ 인데 전번것 ${ }^{6}$ 은 $54.5 \%$, 엑스선검진에서 발견된 것은 각기 $18.6 \%$ 와 $21.1 \%$, 객혈혈담 때문에 병원을 찾 은 것이 각기 $5.1 \%$ 와 $21.1 \%$, 급성폐염양 발병군이 각 기 $2.0 \%$ 와 $3.3 \%$ 인 것을 보면 심하지 않은 자각증상 때 문에도 병원을 찾는 비율이 최근에는 좀 많아졌다고 할 수가 있고 급성폐염양 발병이 언제나 비슷한 것은 페결 핵 발병의 일정한 양상을 보이는 것이라고 할 수가 있다.

초치료폐결핵 환자들이 본원에서 치료를 얼마나 계속하 느냐 하는 것은 매우 중요하다. 그리고 또 우리들은 조 기중단자들의 중단이유를 알아서 대처할 필요가 있는 것 이다. 우선 본원에서 진료회수가 2내지 3 회로 끝나는 환 자의 비율이 이번 것은 전체적으로 $32.4 \%$ 인데 전번것 ${ }^{6}$ 에서는 $50.4 \%$ 인 것을 보면 이 차이는 의료보험 때문에 환자의 부담이 적어졌기 때문이라고 할 수 있다. 이것을 뒷받침하는 것으로서 균양성환자들 중에서 이렇게 조기 퇴록을 하는 사람들은 그 대부분이 의료보험이 없는 사 람들이였다는 사실이다. 또 대체로 충분한 치료효과를 받 을 수 있을 것이라고 생각되는 기간 즉 7 개월이상 치료 를 계속한 균양성 환자가 이번 것에서는 $67.4 \%$ 나 되는 데 전번것 ${ }^{6)}$ 에선 5 개월이상 치료자를 봐도 약 $41 \%$ 뿐인 것도 역시 같은 이유로 해석할 수 있을 것이다.

1966 년도에 발표한 김대규 ${ }^{9)}$ 는 치료중단자의 $32 \%$ 가 경 제적 이유라고 했고 방기문 ${ }^{10)}$ 은 환자의 $54 \%$ 가 무료치료 를 희망했다는 것을 생각해 보고 또 현재 본원을 찾는 환 자의 약 $75 \%$ 가 의료보험 소지자라는 것으로 바서 이상 과 같은 해석이 가능할 것이다.

초치료 폐결핵환자의 치료성적을 치료종결시에 기간별 로 따져본 것에서 보면 3 6개월에서 치료 종결한 환자 는 균음성군이 총수의 $80.4 \%$ (102명 중에 80 명)인데 이 의 $80.5 \%$ 는 비활동성으로 판정됐으니 이들은 비록 치료 기간이 짧았어도 소기의 목적은 달했다고 하겠으며 이것 은 화학요법의 효과보다는 다만 비활동성이라는 진단을 확인했을 뿐이라고 하겠다.

균양성자는 도합에서 겨우 20 명뿐이었으므로 통계적으 
로 큰 의의를 주기는 어렵지만 $75 \%$ 가 균음전, $25 \%$ 가 병 변의 현저한 경쾌를 봤는데 이것은 이미 1957년에 이찬 세 ${ }^{11}$ 가 $\mathrm{SM}, 1 \mathrm{NH}, \mathrm{PAS}$ 를 주축으로한 시대에 폐결핵 치료효과의 출현과정을 본 결과 균음성화는 치료개시후 6 개월이내에 $91.2 \%$ 달성되고 병변의 현저한 경쾌증조는 3 개월이내에 $97.9 \%$ 에서 인정되었다고 한 것과 비교해서 최근에 첨가된 강력한 결핵치료에 의해서 $\mathrm{Fox}^{3}$ 가 주장 하듯이 큰 효과가 그렇게 단기에 나타나는 것은 아니라 고 하겠다.

치료기간 7 10개월에 종결한 환자들에 있어서는 균음 전율이 $97.2 \%$ 이고 병변의 현저한 경쾌를 보인 것이 균 양성자나 음성자나 비슷하고 도합 $48.0 \%$ 이었으며 비할 동성으로 판정된 것도 양자가 비슷한데 도합 $95.0 \%$ 이므 로 대체로 만족한 치료결과라고 할 수 있을 것이다.

그러나 한가지 유의할 일은 경증군에서 균음성화와 비 활동성 판정이 $100 \%$ 달성됐는데 중등증, 중증으로 될 수록 약간씩 저율로 되고 병변의 악화도 소수나마 생긴 다는 것은 병변이 이렇게 진전되기 전에 즉 경증상태에 서 조기진단 조기치료를 해야할 것이라는 것을 시사하는 것이라고 하겠다. 그러나 11 개월이상 치료를 한 환자중 에도 경증환자가 52 명이나 끼여 있는데 이중에서 27 명은 균음성군이었으므로 과잉한 장기치료를 했다고 할 수 있 으나 25 명은 균양성군이고 균음전이 빨리 안되니까 이렇 게 치료기간이 연장되었던 것인데 이들의 대부분은 불규 칙 단속적치료를 했으며 결국 치료실패자로서 병변악화 균양성으로 남은 것이 1 명 (4.00\%)이다.

이러한 것은 결국 폐결핵치료에 있어서는 결핵익품의 우수성뿐 아니라 결핵균과 병변, 그리고 인간인 결핵환 자의 진찰치료행동 등 세가지가 더 첨가 고려되는 합동 작전의 필요성을 의미하는 것이다.

11 개월이상 치료군의 균양자가 88 명의 균음전율은 $94.3 \%$ 음전실패율은 $5.7 \%$ 병변의 현저경쾌율은 38.8 $\%$ 비활동성판정 $87.5 \%$ 병변악화 $3.4 \%$ 로서 대체적 효 과가 치료기간 7 10 개월군에서 것과 비교해 더 많지 않 은 것은 이것이 치료효과의 극대화를 위해서가 아니라 치 료효과가 빨리 나타나지 않아서 부득이 치료기간을 연장 했던 군이였다는' 것을 의미하는 것이기 때문이다.

3 개월이상 치료를 한 환자들에서의 치료효과를 도합해 보면 균양성군 216 명 (총 291명의 $74.2 \%$ ) 중에서 균음전 율은 $94.0 \%$, 음전실패율 $6.0 \%$, 병변의 현저한 경쾌 $39.81 \%$, 비활동성화 $85.2 \%$, 병변악화 $2.8 \%$ 이고 균음
성군 311 명 (총 483 명의 $64.4 \%$ )중에서 균양성화가 2.3 $\%$, 병변의 현저한 경쾌 $35.7 \%$, 비활동성화 $92.6 \%$, 병 변악화율 $1.3 \%$ 이며 이 양자를 도합해서 전체적으로 보 면 초치료환자 856 명의 $61.6 \%$ 가 3 개월이상의 치료를 받 았고 이들의 $89.6 \%$ (472명) 즉 초치료 총등록환자의 55.1 $\%$ 가 비활동성으로 판정되었다.

이러한 성적들을 전번것ㅎ에서 5 개월이상 치료를 하고 만족한 결과로 치료완결한 환자가 $37.4 \%$ 인 것 과 비교하 면 역시 최근의 추가된 결핵약제의 효과와 의료보험에 의 한 치료비부담의 경감에 의해서 대체적 치료효과가 향상 되었다고 할 수 있을 것이다.

초치료 폐결핵환자의 가족중 결핵병력을 보면 한 가족 중에 환자가 4 명 있는 것이 1 예, 3 명 있는 것이 2 예나 있 었다는 것은 아직도 우리나라의 결핵사정이 얼마나 비참 한 것인가 하는 것을 새삼 느끼게 한다. 우리나라의 전 국결핵실태조사 ${ }^{12)}$ 에 의하면 결핵유병률이 그간 많이 감 소되기는 했지만 아직도 선진국가들에 대해서는 말할 것 도 없고 인도 아시아국가들에 비해서도 월등하게 높은 유 병률과 사망률을 가지고 있다는 것을 실지로 알려 주는 것이라고 하겠다. 가족관계별 빈도를 보면 초치료환자의 아버지가 가족내에서 현재 치료중인 환자 64 명중의 15 명 (23.4\%)로 가장 많고 또 과거력이나 사망자를 포함해서 전체 95 명중에서도 27 명 $(28.4 \%)$ 로 가장 많은데 디것은 가족중의 세대주가 되는 아버지가 많다는 점을 생각하면 사회적으로 매우 중대한 일이다. 이러한 사정이 잘 알려 져 있기 때문에 선진국들에서는 결핵치료비의 무료뿐 아 니라 가족의 생계비까지도 대주는 식의 사회보장제도를 채택하고 있는 것이라고 하겠다.

가족내 결핵력에서 부부간보다는 부자녀간 혹은 모자 녀간에서 그 비율이 더 많다는 것은 결국 청소년층의 환 자가 기준환자로 된 비율이 많았다는 것을 의미하는데 $\mathrm{BCG}$ 결핵예방접종의 효력한계를 여실히 보이는 것이라 고 하겠다. 1983년도 국제항결핵연 맹 동부지역회의 보고 서 ${ }^{13)}$ 에서 보면 1981년도에 미취학아동과 취학후아동의 $\mathrm{BCG}$ 접종율이 우리나라는 각기 $80 \%$ 와 $74 \%$ 로서 선진 일 본의 $82 \%$ 와 $95 \%$ 와 비슷하고 또 그 실시연한도 비슷한 데 현재의 결핵실태는 유병률이나 치료중단률에서 20 배 가량이나 차이가 나고 또 지난번 전국실태조사 때에 발 견된 환자의 $59 \%$ 가 미치료자라는 것은 우리나라의 결핵 정책의 재 고려가 요구된다.

1983년도 정부결핵예산의 환자 1 인당 부담액이 우리 
나라는 14,000 원인데 일본은 361,600 원이었고 1961 년에 서 1972년까지 10년동안에 결핵유병률을 $2.5 \%$ 에서 $1 \%$ 로 저하시키는데 무려 2조 5,700억원을 들였는데 우리 나라에서는 1965년의 유병률 (5.1\%)이 1975년에 3.3\% 로 되는 동안 대략 1,200 억원을 들인 것으로 추산된다고 대한 결핵협회 30 년사 ${ }^{13)} \mathrm{p} .48$ 에 제시되고 있는 것으로 봐 서 우리나라에서의 결핵문제는 결핵기술문제가 아니라 재정투자가 문제라는 것을 여실히 알 수 있을 것이다.

\section{결 론}

1983년 8월 1일부터 1987년 1월 31일까지 약 3년 6개 월동안 대한결핵협회 부산지부의원에서 등록 치료한 폐 결핵 초치료환자 856명을 대상으로 해서 결핵치료효과의 향상을 위한 인자를 탐구할 목적으로 조사연구 한 결과 다음과 같은 결과를 얻었다.

1) 초치료환자의 전체 폐결핵환자에 대한 비율은 29.8 $\%$ 로서 과거보다 배가 되었다.

2) 남여의 비율은 1.74 대 1 로서 과거보다 여자의 비율 이 현저히 증가했으나 1985년도 전국결핵실태조사에서 남여 비율과 같으므로 이것은 여자 환자의 치료행위가 증 가한 것이라고 본다.

3) 병변분류를 보면 경증이 $52.6 \%$, 중등증이 $38.8 \%$, 중증이 $8.6 \%$ 로서 과거보다 경증의 비율이 증가했는데 이 것 역시 전기 실태조사에서의 것과 비슷한 점으로 봐서 폐결핵환자들의 전반적인 치료행위가 증가한 것으로 본 다.

4) 연령층별 구성비율을 보면 남여 모두 21 30세층이 월등하게 많아서 $38.2 \%$ 로서 비율은 좀 적지만 과거나 비 슷한 모양의 포물선형 분포를 보이고 전국실태조사에서 보인 고령층을 향해서 점증하는 경향은 없으므로 노령층 의 치료행위는 저조한 것이라고 추측된다.

5) 초진시 객담검사 결과를 보면 전체적으로 균양성자 가 $34.0 \%$ 이고 불검사자는 $9.6 \%$ 로서 과거보다 객담검 사에 더 협조적이었으나 균음성 경증환자가 더 많기 때 문에 양성율은 낮았다.

6) 병세별 병력기간을 보면 균양성자들에 있어서는 병 변이 클수록 길어서 경증에선 3 개월이내가 $76.7 \%$ 인데 중증에선 겨우 $22.0 \%$ 뿐이고 병력기간이 7 개월이상인 중 등증, 중증환자들은 대부분 의료보험이 없는 경제적 하 층계급이었으므로 병원 치료의 문턱이 그들에게는 매우
높기 때문이라고 해석된다.

7) 초진시에 폐결핵 병변의 변화성분류를 보면 변화성 이 많은 것이 $28.6 \%$, 변화성 없는 것이 $27.0 \%$, 중간성 인 것이 $44.4 \%$ 로서 과거보다 변화성이 많은 것이 적었 으나 이것은 무증상, 균음성, 경증환자의 비율이 많았기 때문이라고 하겠다.

8) 발병모양 혹은 진단동기별 구분에서는 서서히 발병 한 것이 $74.3 \%$ 로 과거보다 현저히 증가했고 객혈, 혈담 으로 발병된 것은 $5.1 \%$ 로서 현저히 감소되었으며 엑스 선검진에서 발견된 것은 $18.6 \%$ 급성폐염양발병은 2.0 $\%$ 로서 과거외 비슷했다. 이것은 환자가 자발적으로 병 원을 찾는 비율이 증가했다고 볼 수 있으며 여러가지 경 우에 실시되는 엑스선검진은 아직도 환자발견에 매우 유 용하다는 것을 의미한다.

9) 초치료환자들의 치료계속기간은 2 3회 내원만으 로 끝낸 환자가 $32.4 \%$ 이었으나 이들의 약 절반은 균음 성 무자각 경증환자들로서 비활동성 판정을 받았고 7 개 월이상 치료자는 $67.4 \%$ 로서 이렇게 비교적 충분한 치료 를 받은 자가 전번것 보다 많이 증가했는데 이는 주로 의 료보험실시 덕택이라고 하겠다.

10) 초치료환자의 치료결과를 보면 우선 3 6개월에 치료종결한 자들에서도 균음성화율은 $75.0 \%$ 이고 병변 의 현저한 경쾌도 $25 \%$ 나 되었지만 이것은 그간에 강력 한 결핵제, 리팜피신, 에담부톨, 피라지나마이드, 싸이 클로셀린 등의 첨가에도 불구하고, 과거 스트렙토마이 신, 아이나, 파스에 세가지만으로 치료했던 것에 비해서 큰 차이가 없었다.

$7 \sim 10$ 개월 치료군에서의 균음전율은 $97.2 \%$, 균음전 실패율은 $2.8 \%$, 병변의 현재 경쾌율은 $49.1 \%$, 병변악 화율은 $2.8 \%$ 이고 결국 비활동성으로 판정된 것은 91.7 $\%$ 이었다. 11 개월이상 치료군은 균음전율 $87.5 \%$, 음전 실패율 $5.7 \%$, 병변의 현제경쾌율 $31.8 \%$, 병변악화율 $3.4 \%$ 이고 결국 비활동성으로 된 것은 $87.5 \%$ 이었다. 이 상 전체적인 치유율은 전번의 것보다 많이 향상되었다.

11) 초진시 균음성인 초치료환자중에서 7 10개월 치 료를 한 자는 173 명, 11 개월이상 치료자는 56 명인데 균 이 양전된 것이 각기 $1.7 \%$ 와 $1.8 \%$ 이고 병변이 현저히 경쾌된 것이 $47.4 \%$ 와 $31.9 \%$ 이며 비활동성으로 된 환 자가 각기 $97.1 \%$ 와 $96.4 \%$ 이었다.

12) 병변분류별 환자군에서 보면 병변의 현저한 경쾌 율이 가장 많은 것은 중등증군이었으나 비활동성 판정을 
가장 많이 받은 것은 경증군이다. 균음전 실패율이 가장 많은 것은 중증군인 것을 보면 아무리 강력한 현대적 결 핵치료제를 가지고도 조기진단 조기 치료는 여전히 절대 로 필요하다는 것을 의미한다.

13) 가족내 결핵병력조사에 보면 초치료환자의 11.1 $\%$ 에서 가족중의 결핵력이 인정됬는데 그중에서 현재 치 료중인 가족이 있는 것이 대부분으로서 이들의 $67.4 \%$ (7.5\%)이고 과거력이 있는 것이 $23.2 \%(2.6 \%)$, 결핵 사망자가 있는 것이 $9.5 \%(1.1 \%)$ 이었다. 가족관계를 보 면 가족중의 환자가 초치료환자의 아버지인 경우가 가장 많아서 $28.4 \%(3.2 \%)$ 이고 그 다음이 형제 자매로서 25.3 $\%(2.8 \%)$, 어머니인 경우가 $21.1 \%(2.3 \%)$ 인데 부부간 인 경우는 의외로 적어서 $7.4 \%(0.8 \%)$ 이었다. 이상의 결 과는 초치료환자들의 연령층이 아직도 연소한 경우가 많 았다는 것을 의미한다. 그리고 한 집단에 폐결핵 환자가 4 명 있는 것이 1 예, 3 명 있는 것이 2 예에서 인정됬는데 이러한 일들을 생각해 보면 우리나라에서의 결핵비극은 아직도 매우 심각하다고 안할 수가 없다.

14) 이상을 총괄해 보면 부분적이기는 하지만 정부의 의료보험 실시와 강력한 결핵약제의 보급에 의해서 초치 료 폐결핵환자의 전반적인 치료효과가 상당히 향상되기 는 했지만 조속한 결핵관리의 완성을 위해서는 국민의료 보험의 완성과 사회보장제도의 대대적 확장을 해서 더 적 극적인 조기진단과 조기치료를 할 수 있도록 병원의 문 턱을 낮추고 또 현재의 단기용법정책 뿐만이 아니라 융 통성 있는 최선의 결핵치료법을 연구 보급하면서 환자와 국민들에 대한 보건교육도 적절히 계속할 것을 강조하는 바이다.

\section{REFERENCES}

1) Fox \& Nunn: The Cost of Antituberculosis Drug
Regimens. Am Rev Resp Dis 120:503, 1979

2) 이찬세 : 폐결핵의 단기화학요법과 결핵정책. 인간과 학 $4: 15,1980$

3) Fox \& Mitchison: Short Course Chemotherapy. Am Rev Resp Dis 111:325, 1975

4) 홍영표, 윤영자, 권동원 : 폐결핵 통원 단기치료에 관 한 연구. 대한결핵협회 결핵연구원보 1984

5) 장승칠, 홍영표: 일부지역 보건소에서의 폐결핵 9 개월 단기치료 성적. 결핵 및 호흡기질환 32:19, 1985

6) 이찬세 : 결핵전문의 진료소에서 본 초진 단폐결핵환자 의 귀추·결핵 및 호흡기질환 $17: 5,1970$

7) 이찬세 : 폐결핵 분류법에 관한 연구. 부산의대학보 1 : 83, 1959

8) 1985 년도 전국 결핵실태조사 결과보고. 대한결핵협회 보건사회부

9) 김대규: 치료중단 폐결핵환자의 사회의학적 조사. 결 핵 및 호홉기 질환 22:71, 1966

10) 방기문 : 초진단 폐결핵환자의 사회의학적조사. 결핵 및 호흡기 질환 22:71, 1966

11) 이찬세 : 폐결핵치료에 있어서 몇가지 중요한 문제에 관한 연구. 결핵 및 호흡기질환 $18: 41,1964$

12) 결핵실태와 대책 : 1985 년 대한결핵헙회

13) 대한결핵협회 30 년사 : 대한결핵협회

14) 이찬세 : 폐결핵의 화학요법과 조기치료. 결핵 $4: 86$, 1957

15) 이찬세 : 최근 15 년간의 폐결핵환자의 임상적 동태의 변화. 결핵 및 호흡기질환 22:176, 1975

16) 이찬세 : The Progress and the Course of Pulmonary Tuberculosis Under Chemotherapy. 결핵 13:7, 1961

17) 결핵실태와 대책. 1973년 대한결핵협회

18) 이찬세 : The Diagnosis of the Initial or Relapsed minimal Tuberculosis and the Transient Puenmonic Shadows. Bulletin International Union Against. Tuberculosis 54:217 (Supplement) 1979 